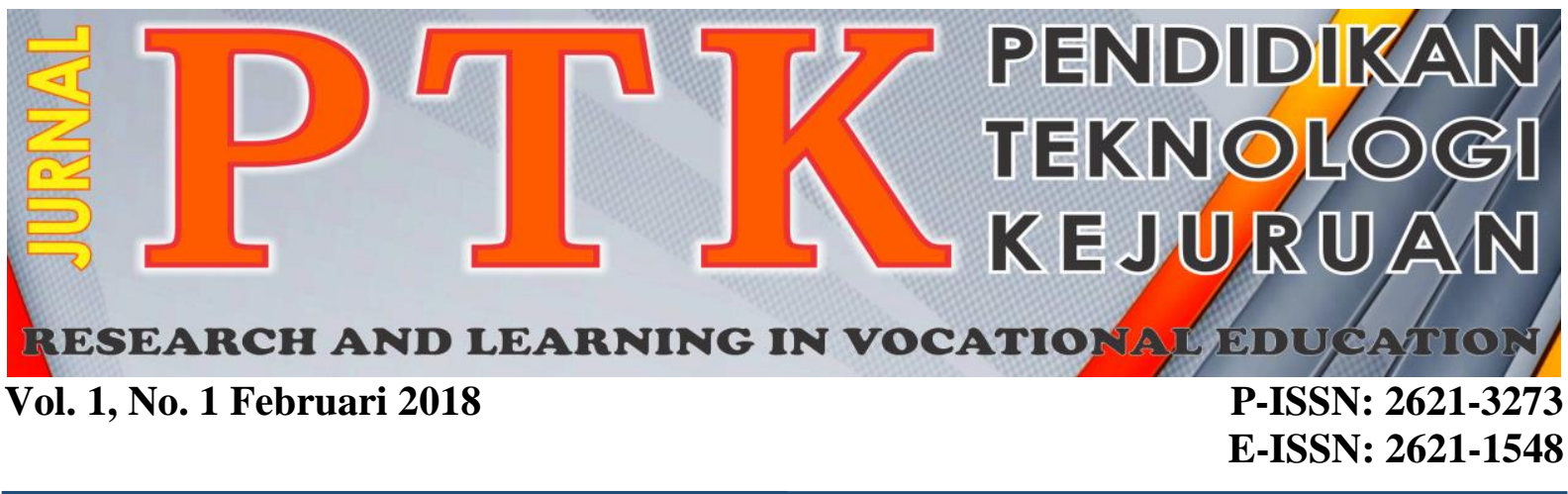

\title{
KONTRIBUSI BAKAT MEKANIK DAN PERSEPSI TENTANG KINERJA GURU TERHADAP PRESTASI BELAJAR PRODUKTIF SISWA KOMPETENSI KEAHLIAN TEKNIK PEMESINAN SMK NEGERI 2 SAWAHLUNTO
}

\author{
Nizwardi Jalinus ${ }^{1}$, Waskito ${ }^{2}$ dan Sudirman ${ }^{3}$ \\ ${ }^{123}$ Pascasarjana, Fakultas Teknik, Universitas Negeri Padang \\ "Corresponding author, e-mail: dirmans76@gmail.com ${ }^{3}$
}

\begin{abstract}
Abstrak - Penelitian ini bertujuan untuk menganalisis dan menjelaskan: (1) kontribusi bakat mekanik terhadap prestasi belajar produktif siswa Kompetensi Keahlian Teknik Pemesinan SMK Negeri 2 Sawahlunto, (2) kontribusi kinerja guru dilihat dari persepsi siswa terhadap prestasi belajar produktif siswa Kompetensi Keahlian Teknik Pemesinan SMK Negeri 2 Sawahlunto, (3) kontribusi bakat mekanik siswa dan kinerja guru dilihat dari persepsi siswa secara bersama-sama terhadap prestasi belajar produktif siswa Kompetensi Keahlian Teknik Pemesinan SMK Negeri 2 Sawahlunto. Penelitian ini menggunakan pendekatan kuantitatif. Teknik pengambilan sampel menggunakan teknik proportional stratified random sampling sebanyak 74 orang dengan Populasi seluruh siswa Kompetensi Keahlian Teknik Pemesinan SMK Negeri 2 Sawahlunto tahun ajaran 2011/2012. Data dianalisis dengan teknik korelasi dan regresi. Hasil analisis menunjukkan bahwa ketiga hipotesis yang diajukan dapat diterima pada taraf kerpercayaan 95\%. Ditemukan bahwa bakat mekanik, kinerja guru, dan bakat mekanik bersama-sama kinerja guru, berkontribusi berturut-turut sebesar17,90\%, 22,60\% dan 27,10\% terhadap prestasi belajar siswa Produktif Kompetensi Keahlian Teknik Pemesinan SMK Negeri 2 Sawahlunto.
\end{abstract}

Kata kunci : Kontribusi, Bakat Mekanik, kinerja guru, prestasi belajar

Abstract-This study was aimed to analyze and explain (1) contribution of students' mechanical aptitude to productive learning achievements of mechanical engineering skill competencies,(2) contribution of teacher performance seen from students' perception to productive learning achievements of mechanical engineering skill competencies,(3) contribution of students' mechanical aptitude and the contribution of teacher performance. The study was conducted on the students based on their productive achievement in mechanical engineering skill competencies class at SMKN 2 Sawahlunto. The research used quantitative approach. The population was all students of mechanical engineering of SMKN 2 Sawahlunto of 2011/2012 academic year. Then the data was analyzed by using the technique of correlation and regression. The result of analysis showed that the three hypotheses were accepted in the percentage level of 95\%. It was found that: a) the mechanical aptitude, teachers competence and mechanical aptitude together with teacher competence contributed 17,90\%, 22,60\% and 27,10\% toward students achievement in productive competence of mechanical.

Keywords: The contribution, Mechanical Aptitude, Teachers' performance, Achievement

\section{Pendahuluan}

Salah satu permasalahan yang dihadapi oleh bangsa kita adalah masih rendahnya kualitas pendidikan; terlihat dari rendahnya standar kelulusan yang ditetapkan. Pada tahun 2004 ketika dilaksanakan Ujian Akhir Nasional (UAN) dengan standar kelulusan 4,01, hasilnya sangat mengagetkan semua pihak. Pada tahun 2011 dilaksanakan Ujian Nasional (UN) yang merupakan penerapan Kurikulum Tingkat Satuan Pendidikan (KTSP) dengan standar kelulusan 
4,50. Hasilnya tidak jauh dengan UN/UAN sebelumnya, walaupun tingkat kelulusan meningkat dibandingkan dengan tahun-tahun sebelumnya.

Banyak hal telah dilakukan untuk meningkatkan mutu pendidikan nasional melalui pelatihan dan peningkatan kualitas guru, penyempurnaan kurikulum, pengadaan buku dan alat pelajaran serta perbaikan sarana dan prasarana pendidikan. Tetapi mutu pendidikan yang dicapai belum seperti apa yang diharapkan.

Pelaksanaan evaluasi mata pelajaran produktif kompetensi keahlian Teknik Pemesinan dilakukan dengan mengacu pada prinsip-prinsip penilaian pendidikan dan pelatihan kejuruan. Untuk mendapatkan prestasi belajar mata pelajaran produktif kompetensi keahlian Teknik Pemesinan yang bersifat kognitif, seorang guru produktif menggunakan model penilaian tertulis berupa pilihan ganda maupun bentuk soal essay. Untuk mendapatkan prestasi belajar yang bersifat psikomotor dan afektif (mata pelajaran Praktik) dilakukan dengan model penilaian berbasis kompetensi berupa penggabungan antara penilaian unjuk kerja, sikap dan project work. Untuk mencapai tujuan dari pembelajaran yakni menghasilkan lulusan yang berdaya saing tinggi, maka perlunya suatu pembenahan dalam proses pembelajaran [1].

Bakat khusus seorang siswa dalam bidang mekanik diperlukan guna mendapatkan prestasi belajar produktif yang tinggi. Menurut Morgan penelusuran bakat khusus dapat dilakukan melalui test penalaran mekanik (Mechanical Reasoning) dan test Kemampuan fisik (Physical Ability) [1]. Test penalaran mekanik digunakan untuk mengungkapkan kemampuan seseorang dalam menangkap atau memahami prinsip-prinsip umum fisika sebagai dasar bekerja dalam bidang mekanik. Sedangkan test physical ability digunakan untuk mengungkapkan kemampuan seseorang secara fisik, meliputi kekuatan, ketangkasan, keterampilan dan kemampuan menyelesaikan masalah di lapangan.

Selain bakat mekanik, faktor lain yang tidak kalah pentingnya dalam menunjang prestasi belajar peserta didik adalah kinerja guru (teacher performance) yang berkaitan dengan kompetensi guru. Kinerja guru merupakan perwujudan kompetensi guru yang mencakup kemampuan dan motivasi untuk menyelesaikan tugas pengembangan diri. Menurut Depdiknas, kinerja guru adalah kemampuan guru untuk mendemonstrasikan berbagai kecakapan dan kompetensi yang dimilikinya dalam PBM [2]. Kinerja guru sangat penting untuk diperhatikan dan dievaluasi karena dari situlah prestasi belajat siswa terutama berasal.

Indikator kinerja guru kejuruan meliputi hal berikut:

a. Kemampuan membuat perencanaan dan persiapan mengajar.

b. Penguasaan materi yang akan diajarkan kepada siswa baik dalam tataran konsep maupun praktiknya.

c. Kemampan pembuatan tugas-tugas ke pada siswa baik teori maupun tugas-tugas praktik (Job sheet),

d. Kemampuan mengelola kelas dan bengkel dalam bentuk pembelajaran teori dan pembelajaran praktik.

e. Kemampuan melakukan penilaian dan evaluasi baik formative, summative maupun competence evaluation

Salah satu faktor yang mempengaruhi prestasi belajar siswa adalah variabel guru. Guru mempunyai pengaruh yang cukup dominan terhadap kualitas pembelajaran, karena gurulah yang bertanggungjawab terhadap proses pembelajaran di kelas [3]. Tugas seorang guru profesional meliputi tiga bidang utama yaitu dalam bidang profesi, kemanusiaan, dan kemasyarakatan. Dalam bidang profesi, seorang guru profesional berfungsi untuk mengajar, mendidik, melatih, dan melaksanakan penelitian masalah-masalah pendidikan. Dalam bidang kemanusiaan, guru profesional berfungsi sebagai pengganti orang tua khususnya didalam bidang peningkatan kemampuan intelektual peserta didik. Guru profesional menjadi fasilitator untuk membantu peserta didik mentransformasikan potensi yang dimiliki peserta didik menjadi kemampuan serta keterampilan yang berkembang dan bermanfaat bagi kemanusiaan.

Kegiatan penelusuran bakat mekanik siswa belum ada dilakukan di SMK Negeri 2 Sawahlunto; penerimaan siswa baru hanya berdasarkan nilai UN saja. Banyak siswa ditemukan mengalami kesulitan dalam belajar yang ditunjukkan dengan rendahnya motivasi siswa dalam mengikuti proses belajar mengajar dalam bentuk gelisah, jenuh dan lain-lainnya. Persentase siswa yang Drop Out termasuk tinggi, juga nilai yang di bawah Kriteria Ketuntasan Minimal (KKM); termasuk banyaknya siswa yang tidak naik kelas ke jenjang berikutnya (lihat Tabel 1) 
Tabel 1. Keadaan Siswa Kelas X Semester 2 Tahun Pelajaran 2010/2011 SMK Negeri 2 Sawahlunto

\begin{tabular}{clcccc}
\hline No. & Program Keahlian & Kondisi Awal & Kondisi Akhir & $\begin{array}{c}\text { Jumlah Siswa } \\
\text { Droup Out }\end{array}$ \\
\hline 1. & Teknik Kendaraan Ringan & 70 & 61 & 9 & Kelas RSBI \\
\hline 2. & Teknik Pemesinan & 68 & 50 & 18 & Kelas RSBI \\
\hline 3. & Teknik Konstruksi Kayu & 36 & 20 & 6 & \\
\hline 4. & Teknik Instalasi Tenaga Listrik & 36 & 30 & 7 \\
\hline 5. & Geologi Pertambangan & 65 & 58 & $\mathbf{5 6}$ \\
\hline & Jumlah & $\mathbf{2 7 5}$ & $\mathbf{2 1 9}$ & \\
\hline
\end{tabular}

Tabel 2. Prestasi belajar Siswa Siswa Kelas X Tahun Pelajaran 2010/2011 SMK Negeri 2 Sawahlunto

\begin{tabular}{|c|c|c|c|c|c|}
\hline No. & Program Keahlian & Kelas & $\begin{array}{c}\text { Jumlah } \\
\text { Siswa }\end{array}$ & $\begin{array}{c}\text { Jlh. Siswa Tidak } \\
\text { Naik }\end{array}$ & Keterangan \\
\hline \multirow[t]{2}{*}{1.} & \multirow[t]{2}{*}{ Teknik Kendaraan Ringan } & XTKR1 & 30 & 10 & Kelas RSBI \\
\hline & & XTKR2 & 31 & 8 & \\
\hline \multirow[t]{2}{*}{2.} & \multirow[t]{2}{*}{ Teknik Pemesinan } & XTPM1 & 27 & 10 & Kelas RSBI \\
\hline & & XTPM2 & 23 & 6 & \\
\hline 3. & Teknik Konstruksi Kayu & XKY & 20 & 8 & \\
\hline 4. & Teknik Instalasi Tenaga Listrik & XTITL & 30 & 0 & \\
\hline \multirow[t]{3}{*}{5.} & \multirow[t]{2}{*}{ Geologi Pertambangan } & XGP1 & 28 & 6 & \\
\hline & & XGP2 & 30 & 7 & \\
\hline & J u m l a h & & 219 & 55 & \\
\hline
\end{tabular}

Sumber : Waka Kurikulum SMK Negeri 2 Sawahlunto

Kinerja guru nampak masih rendah. Hal ini terlihat dari rendahnya kemampuan yang dimiliki guru berkenanan dengan penguasaan terhadap karakteristik yang dimiliki siswa baik dari aspek fisik, moral, sosial, kultur, emosional dan intelektual; banyak guru menyamaratakan siswa dalam proses pembelajaran.

Juga masih terlihat rendahnya kemampuan guru dalam merencanakan kegiatan pembelajaran. Masih ada guru produktif yang belum memahami Kurikulum Tingkat Satuan Pendidikan /Spectrum 2008 dalam pembuatan silabus dan Rencana Proses Pembelajaran. Juga masih banyak guru produktif tidak memberikan silabus pada siswa di awal pembelajaran. Kemampuan guru dalam melaksanakan penilaian kemampuan siswa juga belum optimal. Guru produktif Teknik Pemesinan SMK Negeri 2 Sawahlunto dalam menilai kemampuan siswa hanya melihat dari aspek kemampuan psikomotorik, itupun hanya melihat hasil akhir kerja siswa saja. Hal ini jelas tidak memenuhi aspek penilaian prestasi belajar yang sempurna, yakni aspek kognitif, afektif, dan psikomotorik [4].

Mengingat berbagai keterbatasan, peneliti hanya akan meneliti faktor bakat siswa dalam hal ini bakat mekanik, serta kinerja guru dilihat dari persepsi siswa. Faktor bakat terutama bakat mekanik memegang peranan penting dalam proses belajar terutama belajar keterampilan. Sedangkan faktor kinerja guru penentu keberhasilan suatu proses pendidikan secara teknis [3].

Berdasarkan hal di atas, maka rumusan permasalahan dalam penelitian ini adalah: 1) Berapa besar korelasi bakat mekanik terhadap prestasi belajar produktif siswa Kompetensi Keahlian Teknik Pemesinan di SMK Negeri 2 Sawahlunto. 2) Berapa besar korelasi persepsi siswa tentang kinerja guru terhadap prestasi belajar produktif siswa Kompetensi Keahlian Teknik Pemesinan di SMK Negeri 2 Sawahlunto. 3) Berapa besar korelasi antara bakat mekanik dan persepsi siswa tentang kinerja guru secara bersama-sama terhadap prestasi belajar produktif siswa Kompetensi Keahlian Teknik Pemesinan di SMK Negeri 2 Sawahlunto.

Sedangkan hipotesis yang diajukan dalam penelitian ini berturut-turut adalah sebagai berikut: Bakat mekanik siswa, Kinerja guru, dan Bakat mekanik bersama-sama kinerja guru berkorelasi positif dan signifikan terhadap prestasi belajar produktif pada siswa kompetensi keahlian Teknik Pemesinan SMK Negeri 2 Sawahlunto.

\section{Metode Penelitian}

Penelitian ini adalah penelitian kuantitatif dengan menggunakan pendekatan korelasional. Menurut Sukardi penelitian korelasional mempunyai tiga karakteristik penting untuk para peneliti yang hendak menggunakannya, yaitu: (1) 
penelitian korelasional tepat jika variabel kompleks dan peneliti tidak mungkin melakukan manipulasi dan mengontrol variabel seperti dalam penelitian eksperimen, (2) memungkinkan variabel diukur secara intensif dalam setting (lingkungan) nyata, dan (3) memungkinkan peneliti mendapat derajat asosiasi yang signifikan. Sedangkan analisis yang digunakan dalam penelitian ini adalah analisis deskriptif [5].

Populasi penelitian ini adalah semua siswa Kompetensi Keahlian Teknik Pemesinan SMK Negeri 2 Sawahlunto tahun pelajaran 2011/2012 yang berjumlah 144 orang. Untuk pengambilan sampel penelitian menggunakan teknik proportionate stratified random sampling dengan jumlah sampel terpilih sebanyak 74 orang

Teknik pengumpulan data (instrumen) terdiri dari Tes bakat mekanik dengan menggunakan instrumen yang telah standar yakni Mechanical Reasoning yang dikembangkan oleh Paul Newton dan Helen Bristoll. Selanjutnya angket (kuesioner), digunakan untuk mengetahui kinerja guru berdasarkan persepsi siswa. Juga digunakan data dokumentasi, termasuk mengolah hasil belajar produktif.. Teknik analisis data pada penelitian ini diarahkan untuk menguji hipotesis dan menjawab perumusan masalah yang diajukan.
Uji statistiknya ialah analisis parametrik memakai Product Moment. Untuk hipotesis pertama dan kedua menggunakan teknik korelasi dan regresi sederhana. Sedangkan teknik analisis data yang digunakan untuk hipotesis ketiga menggunakan teknik korelasi ganda. Untuk memeriksa besarnya kontribusi murni variabel $\mathrm{x}_{1}$ (bakat mekanik siswa) dan $\mathrm{x}_{2}$ (kinerja guru dilihat dari persepsi siswa) terhadap variabel y (prestasi belajar produktif kompetensi keahlian Teknik Pemesinan SMK Negeri 2 Sawahlunto) digunakan analisis parsial.

Pengujian persyaratan analisis meliputi uji normalitas dilakukan dengan uji Kolmogorov Smirnov, uji linieritas garis regresi dilakukan dengan menggunakan teknik regresi sederhana dan uji multikoliniearitas dengan melihat nilai Inflation Factor (VIF) pada model regresi.

\section{HASIL DAN PEMbahasan}

Dari hasil penelitian yang telah dilakukan terhadap data yang ada, seluruh data memenuhi syarat untuk diolah dan dianalisis. Temuan yang didapat berdasarkan analisis data sebagai berikut:

Tabel 3. Perhitungan Statistik Dasar Variabel $\mathrm{X}_{1}, \mathrm{X}_{2}$, dan $\mathrm{Y}$.

\begin{tabular}{llrrrr}
\hline & & Bakat Mekanik & Kinerja Guru & \multicolumn{2}{c}{ Prestasi Belajar } \\
\hline $\mathrm{N}$ & Valid & 74 & 74 & 74 \\
\cline { 2 - 5 } & Missing & 0 & 0 & 0 \\
\hline Mean & 9.91 & 131.34 & 75.7447 \\
\hline Std. Error of Mean & .272 & 1.399 & .37216 \\
\hline Median & 10.00 & 133.00 & 75.6250 \\
\hline Mode & $9^{\mathrm{a}}$ & 135 & 72.50 \\
\hline Std. Deviation & 2.336 & 12.038 & 3.20145 \\
\hline Variance & 5.457 & 144.912 & 10.249 \\
\hline Range & 10 & 67 & 15.50 \\
\hline Minimum & 5 & 92 & 70.00 \\
\hline Maximum & 15 & 159 & 85.50 \\
\hline Sum & 733 & 9719 & 5605.11 \\
\hline
\end{tabular}

Tingkat pencapaian responden pada variabel bakat mekanik siswa sebesar $49,55 \%$ (kategori kurang).Variabel kinerja guru sebesar $82,09 \%$ (kategori baik), sedangkan variabel prestasi belajar siswa adalah sebesar $75,75 \%$ (kategori cukup).
Pengujian normalitas data dilakukan dengan menggunakan uji Lilliefors dengan melihat nilai pada Kolmogorov Smirnov; dasar penolakan atau penerimaan keputusan normal tidaknya distribusi data ditetapkan pada taraf siginifikan alpha 0,05 . Tabel 4 dibawah ini mengindikasikan semua variabel berdistribusi normal. 
Tabel 4. Uji Normalitas variabel $\mathrm{X}_{1}, \mathrm{X}_{2}$ dan $\mathrm{Y}$

\begin{tabular}{lccrrrrr}
\hline & \multicolumn{3}{c}{ Kolmogorov-Smirnov $^{\mathrm{a}}$} & \multicolumn{3}{c}{ Shapiro-Wilk } \\
\hline & \multicolumn{1}{c}{ Statistic } & df & Sig. & Statistic & df & \multicolumn{1}{c}{ Sig. } \\
\hline Bakat Mekanik & .099 & 74 & .068 & .970 & 74 & .077 \\
\hline Kinerja Guru & .091 & 74 & $.200^{*}$ & .975 & 74 & .141 \\
\hline Prestasi Belajar & .066 & 74 & $.200^{*}$ & .972 & 74 & .105 \\
\hline
\end{tabular}

Pada uji linearitas garis regresi $X_{1}, X_{2}$ terhadap $Y$, nilai masing-masing signifikansi (Linearity) untuk $\mathrm{Y}-\mathrm{X}_{1}$ sebesar 0,000 dan $\mathrm{Y}-$ $\mathrm{X}_{2}$ sebesar 0,000 Sedangkan nilai siginifikansi alpha yang digunakan adalah 0,05. Disimpulkan bahwa sebaran data pada variabel Bakat Mekanik Siswa dan Kinerja Guru cenderung membentuk garis linier terhadap variabel Prestasi Belajar Siswa Produktif Kompetensi Keahlian Teknik Pemesinan.

Hasil analisis Uji Multikolineritas/ Independensi diperoleh nilai Inflation Factor (VIF) untuk variabel Bakat Mekanik dan Kinerja Guru sebesar 1,338. Karena nilai Inflation Factor (VIF) kurang dari 5, maka disimpulkan tidak terjadi masalah multikolinearitas.

\section{a. Hasil Analisis Korelasi Bakat mekanik Siswa $\left(\mathbf{X}_{1}\right)$ terhadap Prestasi Belajar Siswa (Y)}

Analisis korelasi Bakat Mekanik $\left(\mathrm{X}_{1}\right)$ memberikan gambaran bahwa koefisien korelasi antara Bakat Mekanik dengan Prestasi Belajar $\left(\mathrm{rx}_{1} \mathrm{y}\right)$ sebesar 0,423 dengan (sig.2-tailed $\left.=0,000\right)$ dengan kontribusi sebesar $17,9 \%$. Hal ini berarti terdapat hubungan positif dan signifikan tetapi cenderung rendah antara Bakat Mekanik dengan Prestasi Belajar.

Tabel 5. Analisis korelasi Variabel $\mathrm{X}_{1}$ terhadap Variabel Y

\begin{tabular}{rrrrr}
\hline Model & R & R Square & $\begin{array}{l}\text { Adjusted } \\
\text { R Square }\end{array}$ & $\begin{array}{r}\text { Std. Error of } \\
\text { the Estimate }\end{array}$ \\
\hline 1 & $.423^{\mathrm{a}}$ & .179 & .168 & 2.92085 \\
\hline
\end{tabular}

Hal ini berarti bahwa terjadi hubungan yang searah dari variabel Bakat Mekanik Siswa dengan Prestasi Belajar produktif; semakin tingginya bakat mekanik siswa tidak serta-merta membuat semakin tingginya Prestasi Belajar produktif kompetensi keahlian Teknik Pemesinan SMK Negeri 2 Sawahlunto. Hal ini terlihat dari hasil tes bakat mekanik yang dilakukan pada masingmasing responden; siswa yang mendapat hasil tes tinggi cenderung mempunyai prestasi belajar produktif yang tinggi pula.

Hasil tes bakat mekanik siswa kompetensi keahlian Teknik Pemesinan SMK Negeri 2 Sawahlunto menunjukkan tingkat pencapaian dari skor ideal masih dalam kategori cukup. Hal ini diharapkan pihak sekolah maupun pihak stakeholder pendidikan kejuruan memberikan peluang untuk menggali bakat-bakat dalam bidang mekanik yang nantinya berimbas pada prestasi belajar siswa, khususnya mata pelajaran produktif. Sehingga, siswa tidak mengalami kegelisahan, kesulitan dalam mengikuti proses pembelajaran di Kompetensi Keahlian Teknik Pemesinan SMK Negeri 2 Sawahlunto.

\section{b. Hasil Analisis Korelasi Kinerja guru $\left(\mathbf{X}_{2}\right)$ terhadap Prestasi Belajar Siswa (Y)}

Hasil analisis korelasi Kinerja Guru $\left(\mathrm{X}_{2}\right)$ memberikan gambaran bahwa koefisien korelasi antara Kinerja Guru dengan Prestasi Belajar $\left(\mathrm{rx}_{2} \mathrm{y}\right)$ sebesar 0,475 dengan (sig.2-tailed $=0,000$ ) dengan kontribusi sebesar $22,6 \%$.

Tabel 6. Analisis korelasi Variabel $\mathrm{X}_{2}$ terhadap Variabel Y

\begin{tabular}{|c|c|c|c|c|}
\hline Model & $\mathrm{R}$ & R Square & $\begin{array}{c}\text { Adjusted R } \\
\text { Square }\end{array}$ & $\begin{array}{l}\text { Std. Error of the } \\
\text { Estimate }\end{array}$ \\
\hline 1 & $.475^{\mathrm{a}}$ & .226 & .215 & 2.83654 \\
\hline
\end{tabular}

Hasil penelitian menunjukkan bahwa unsur kinerja guru yang dilihat dari persepsi siswa berkorelasi positif yang signifikan terhadap prestasi belajar produktif kompetensi keahlian Teknik Pemesinan SMK Negeri 2 Sawahlunto yakni sebesar 0,475 dan kontribusi sebesar $22,60 \%$. Ini berarti semakin tinggi tingkat kinerja guru maka semakin tinggi pula prestasi belajar siswa. Juga dari hasil penelitian beberapa indikator terhadap kinerja guru produktif kompetensi keahlian Teknik Pemesinan SMK Negeri 2 Sawahlunto menunjukkan kinerja guru dalam kategori relatif baik, meskipun beberapa item dari indikator yang diteliti masih rendah. 


\section{c. Hasil Analisis Korelasi Bakat Mekanik $\left(\mathbf{X}_{1}\right)$} dan Kinerja Guru $\left(\mathrm{X}_{2}\right)$ secara bersamasama terhadap Prestasi Belajar (Y)

Koefisien korelasi antara Bakat Mekanik dan Kinerja Guru dilihat dari persepsi siswa $\left(\mathrm{rx}_{1} \mathrm{X}_{2} \mathrm{y}\right)$ bersama-sama terhadap prestasi belajar produktif siswa $(\mathrm{Y})$ sebesar 0,521 dengan analisis determinasi sebesar 0,271 atau sebesar 27,10\%. Hal ini menunjukkan bahwa persentase sumbangan pengaruh variabel Bakat Mekanik dan Kinerja Guru secara bersama-sama terhadap prestasi belajar sebesar 27,10\%. Sedangkan sisanya $72,90 \%$ dipengaruhi atau dijelaskan oleh variabel lain yang tidak dimasukkan dalam model penelitian ini.
Tabel 7. Analisis korelasi Variabel $\mathrm{X}_{1}$ dan $\mathrm{X}_{2}$ bersamasama terhadap Variabel Y

\begin{tabular}{lrrrr}
\hline Model & $\mathrm{R}$ & \multicolumn{2}{c}{$\mathrm{R}$} & \multicolumn{2}{c}{$\begin{array}{c}\text { Adjusted R } \\
\text { Square }\end{array}$} & $\begin{array}{c}\text { Std. Error of the } \\
\text { Square }\end{array}$ & \multicolumn{1}{c}{ Estimate } \\
\hline 1 & $.521^{\mathrm{a}}$ & .271 & .251 & 2.77128 \\
\hline
\end{tabular}

Untuk memprediksi nilai dari variabel dependen $(\mathrm{Y})$ dari dua variabel independen $\left(\mathrm{X}_{1}\right.$ dan $\mathrm{X}_{2}$ ) digunakan persamaan regresi linier berganda dengan persamaan $\hat{Y}=a+b_{1} X_{1}+b_{2} X_{2}$ $=60,130+0,338 X_{1}+0,093 X_{2}$. Jadi jika bakat mekanik dan kinerja guru mengalami kenaikan 1 (satu), maka Prestasi Belajar $(\hat{Y})$ akan mengalami peningkatan $60,130+0,338+0,093 \times 1=60,561$. Koefisien bernilai positif artinya terjadi hubungan positif antara Bakat Mekanik dan Kinerja Guru secara bersama-sama terhadap Prestasi Belajar, semakin tinggi Bakat Mekanik dan Kinerja Guru maka semakin tinggi Prestasi Belajar siswa.

Tabel 8. Hasil Analisis regresi

\begin{tabular}{|c|c|c|c|c|c|c|}
\hline & \multirow{2}{*}{ Model } & \multicolumn{2}{|c|}{ Unstandardized Coefficients } & \multirow{2}{*}{$\begin{array}{c}\text { Standardized } \\
\text { Coefficients }\end{array}$} & \multirow[t]{2}{*}{$\mathrm{T}$} & \multirow{2}{*}{ Sig. } \\
\hline & & $\mathrm{B}$ & Std. Error & & & \\
\hline \multirow[t]{3}{*}{1} & (Constant) & 60.130 & 3.584 & & 16.778 & .000 \\
\hline & Bakat Mekanik & .338 & .161 & .247 & 2.105 & .039 \\
\hline & Kinerja Guru & .093 & .031 & .351 & 2.997 & .004 \\
\hline
\end{tabular}

Dalam penelitian ini, untuk mengetahui kontribusi murni suatu variabel bebas dengan variabel terikat dengan mengontrol variabel bebas lainnya digunakan korelasi parsial. Adapun rangkuman hasil analisis kontribusi relatif dan kontribusi efektif dari masing masing variabel bebas, dapat dilihat pada tabel di bawah ini:

Tabel 9. Rangkuman Hasil Analisis Kontribusi Murni, Kontribusi Relatif, dan Kontribusi Efektif variabel $\mathrm{X}_{1}$ dan $\mathrm{X}_{2}$

\begin{tabular}{cccc}
\hline Variabel & Kontribusi Murni & Kontribusi Relatif & Kontribusi Efektif \\
\hline $\mathrm{X}_{1}$ & $5,85 \%$ & $21,55 \%$ & $5,84 \%$ \\
\hline $\mathrm{X}_{2}$ & $11,22 \%$ & $78,45 \%$ & $21,26 \%$ \\
\hline Jumlah & $\mathbf{1 7 , 0 7 \%}$ & $\mathbf{1 0 0 \%}$ & $\mathbf{2 7 , 1 0 \%}$ \\
\hline
\end{tabular}

Hasil analisis di atas menunjukkan masingmasing variabel bebas terhadap variabel terikat dengan mengabaikan adanya interkorelasi antar kedua variabel bebas dapat dinyatakan bahwa bakat mekanik dan kinerja guru merupakan faktor yang cukup berpengaruh terhadap prestasi belajar produktif siswa kompetensi keahlian Teknik Pemesinan SMK Negeri 2 Sawahlunto, sehingga perlu upaya yang terus-menerus oleh siswa maupun guru dalam meningkatkan prestasi belajar produktif.

Dengan demikian untuk meningkatkan prestasi belajar produktif kompetensi keahlian Teknik Pemesinan SMK Negeri 2 Sawahlunto. dapat dilakukan dengan berusaha meningkatkan kinerja guru melalui peningkatkan keterampilan mengajar, baik melalui jalur pendidikan, studi banding maupun diklat. Selain itu, sekolah juga diharapkan dapat mampu melatih/ menggali bakat-bakat dalam bidang mekanik siswa serta dalam penerimaan siswa baru memasukan tes bakat mekanik dalam penerimaan siswa baru yang nantinya berimbas pada prestasi belajar siswa khususnya mata pelajaran produktif.

\section{SIMPULAN DAN SARAN}

Berdasarkan hasil penelitian yang meliputi tiga variabel yaitu Bakat Mekanik Siswa $\left(\mathrm{X}_{1}\right)$, Kinerja Guru $\left(\mathrm{X}_{2}\right)$ dan Prestasi Belajar (Y) 
produktif Kompetensi Keahlian Teknik Pemesinan di SMK Negeri 2 Sawahlunto dapat ditarik kesimpulan yaitu variabel $\mathrm{x}_{1}$ (Bakat Mekanik Siswa), $\mathrm{x}_{2}$ (Kinerja Guru) serta $\mathrm{x}_{12}$ (Bakat mekanik siswa bersama-sama Kinerja Guru) memberikan kontribusi berturut-turut sebesar $17,90 \%, 22,60 \%$ dan 27,10\% terhadap Prestasi Belajar produktif siswa kompetensi keahlian teknik pemesinan SMK Negeri 2 Sawahlunto, sedangkan korelasi antara variabel $\mathrm{x}_{1}$ dan $\mathrm{x}_{2}$ terhadap $\mathrm{y}$, juga $\mathrm{x}_{12}$ terhadap $\mathrm{y}$ hanya berada pada tingkat sedang. Hal ini menunjukkan bahwa Bakat Mekanik merupakan faktor cukup penting dalam upaya mencapai prestasi belajar produktif Siswa Kompetensi Keahlian Teknik Pemesinan SMK Negeri 2 Sawahlunto.

Sebagai saran untuk berbagai pihak dapat diajukan sebagai berikut:

1. Bagi siswa, hendaknya menentukan program keahlian yang berdasarkan ats kemampuan mekanik yang dimiliki, serta selalu berpikir kreatif dan inovatif selama mengikuti proses pembelajaran khususnya mata pelajaran produktif ini.

2. Untuk sekolah kejuruan, Test bakat mekanik hendaknya digunakan untuk membantu siswa merencanakan karir (menentukan program keahlian) maupun studi lanjutan bagi siswa.

3. Guru Produktif Kompetensi Keahlian Teknik Pemesinan, agar lebih meningkatkan lagi kinerjanya. Upaya-upaya yang dapat dilakukan melalui peningkatkan keterampilan mengajar, baik melalui jalur pendidikan, studi banding maupun diklat.

4. Bagi para pengambil kebijakan, dapat membuat kebijakan-kebijakan dalam Penerimaan Siswa Baru (PSB) untuk melakukan penyaringan siswa baru dengan memasukkan salah satu tes bakat mekanik dalam kebijakan.

5. Bagi peneliti selanjutnya, hasil penelitian ini mengisyaratkan masih banyak terdapat variabel lain yang berkontribusi terhadap prestasi belajar produktif siswa, diharapkan dapat dilakukan penelitian-penelitian lebih lokus maupun fokus. Khusus untuk variabel bakat mekanik, disarankan untuk melakukan penelitian lebih lanjut dengan memasukkan unsur tes ketrampilan dan karakter.

\section{Daftar Pustaka}

[1] Morgan, Intoduction to Psychology. Toronto: Mc Graw-Hill, 1986.

[2] Depdiknas, Pedoman Supervisi Pengajaran. Jakarta: Depdiknas, 2004.

[3] M. Donald, "The structure of teaching effectiveness," Encycl. Educ. Res., vol. 4, 1982.

[4] S. Nasution, Didaktik Asas-asas Mengajar. Jakarta: Bumi Aksara, 1995.

[5] Sukardi, Metodologi Penelitian Pendidikan: Kompetensi dan Praktiknya. Jakarta: PT. Raja Grafindo Persada, 2008. 